\title{
Application Prospects for Harmless Treatments of Oily Sludge in Changqing Oilfield
}

\author{
Chunmei Xu, Weiyu Bi, Xiaorong Li, Haien Yang, Fangfang Xue, Ping Yi \\ National Engineering Laboratory for Exploration and Development of Low Permeability Oil and Gas Field \\ Oil \& gas technology research institute of Changqing Oilfield Company \\ Shaanxi Province 710018 \\ email:xcm_cq@petrochina.com.cn
}

\begin{abstract}
Treatment of oily sludge in Changqing oilfield, originating from producer/injector well field and settling tanks of united stations, has ever been an obsession in the development of oilfield for environmental concerns. In this article, some merits of oily sludge, including salinityresistance, shearing-resistance and matchability with formation, are analysed. In the background of present development stage for Changqing oilfield, where the numbers of high water-cut producers are increasing, the point of using oily sludge as conformance-control agents is put forward.
\end{abstract}

Keywords- Changqing oilfield; oily sludge; harmless treatment; conformence control

\section{INTRODUCTION}

There exist two kinds of oily sludge in Changqing oilfield: one is from well fields in the course of oil recovery, especially when blowing off; the other is from free settling of crude oil in settling tanks, storage tanks and sewage pools in the course of gathering and transportation.

Containing plenty of pathogen, parasites, heavy metals, such as chromium and mercury, and hardly degraded poison, such as polychlorinated biphenyls, dioxin, and radionuclides, the sludge was hoped to deposit in time to avoid environmental pollution and wastement of crude $\mathrm{oil}^{[1]}$. From these aspects, harmless treatment of oily sludge was highly desirable. Some technologies with good recovery rate have been developed, but high investment and complicated procedures accompanying this inhibited their application in large scale. In this article, drawing lessons from other oilfields, we thought it economical and reasonable using sludge as conformance control agents.

\section{OILY SLUDGE OUTPUT IN CHANGQING OILFIELD}

Table 1 was bottom sludge output statistical data from settling tanks in united stations of 6 oil-production plants in Changqing in 2010, where the output from sewage disposal was not included for their inaccessibility. Collectively, the output of oily sludge in Changqing oilfield was estimated to be $2 \times 10^{4}$ tons annually.
Table 1: Output of sludge from settling tanks in 6 oil-production plants

\begin{tabular}{cccccccc}
\hline plants & $\# 1$ & $\# 2$ & $\# 3$ & $\# 4$ & $\# 5$ & $\# 6$ & total \\
\hline output/ton & 8000 & 1000 & 4600 & 5000 & 300 & 80 & 18980 \\
\hline
\end{tabular}

\section{DAMAGES FROM OILY SLUDGES}

Produced in large amounts and having diversified poisonous impurity, sludges are desired to be harnessed properly for avoiding the probable issues below:

i) During sewage reinjection technology, the level of suspended solids in reinjection water, resulting from sewage tanks, was impermissibly high and formation would be pluged. Consequently injection pressure is increased and the period of validity for stimulation on injection wells shorted, which result in added operational costs and workload.

ii) To avoid the circulation of suspended matter in injection system, a multitude of sewage has to be drained, leading to a waste of water and pollution to surroundings.

iii) For proper storage of oily sludge in large amounts with the least effect on environment, increased costs are resultant.

Taking together, it is becoming an urgent task to harness the oily sludge in a harmless manner.

\section{TECHNICAL STATUS OF TREATMENTS AGAINST OILY SLUDGE}

The processes and equipments for treatments are varied, in accordance with the complicated composition of sludge, which generally comprise burning, biological, heating and washing ${ }^{[2]}$, solvent extraction ${ }^{[3]}$ and chemical demulsification etc, from which some are reviewed respectively as follows.

i)Modulation-mechanical separations

A series of new type polymer flocculants have been indentified ed with high efficiency for modilation chemically of sludges, which has been developed extensively abroad. When exposed with flocculants for oily sludge, the particulates were altered, stability of colloids collapsed, followed by mechanical dehydrations. Upon stirring in the presence of emulsifiers, the mixtures entered tri-phrase centrifuge, where oil, water and muds were separated. In this course, choice of emulsifier, 
mud/water ratio, stirring velocity and temperature were important parameters ${ }^{[2]}$.

ii)Solvent extractions

Solvent extractions was adopted widely for removing oil and organics entrained within sludge. In this process, the oily sludge was mixed with solvent firstly. Then afer stirring and centrifugation, most organics and oil from sludge were recovered from the extract, from which solvent was distilled off and recycled. Through this process, the most residue from sludge fulfill the requirements of BDAT(Best Demonstrated Available Technology). As for residues containing heavy oil in large amount, reextraction by means of high-order hydrocarbons as solvent was necessary. Alternatively, sream distillation was performed, which would effectively remove mor than $90 \%$ of heavy oil from sludge.

iii)Biological pathways

The principle behind this was assimilation degradation of petroleum hydrocarbon in the presence of microbes, with the final results of complete mineralization and turning into small inorganics $\left(\mathrm{CO}_{2}\right.$ and $\left.\mathrm{H}_{2} \mathrm{O}\right)$. Compositing and biological reaction are the two typical technics used.

In compositing, the oily sludge was mixed with suitable substance and piled up together, where the petroleum hydrocarbon was degraded by natural microbes. In the modes of in-bank, static, closed and in-container generally, compositing was considered an effective treatment, after which the residue may be sent to farmlands for fertilizer, with the half life of hydrocarbon in about 2 weeks.

Biological reactions for treating sludge was excuted in customized reactors containing nutritional medium, where the sludge was dispersed into slurry. Because of readily turning of operational conditins, such as oxygen content, temperature and nutritions, biologica degradation in this reactor was fast compared with that in other biological process. According to the report, the half life of degradation was 5 days with the loading of feedstock at $5 \%$.

iv)Oily sludge as conformance-control agents

With the assistance of additives, stable emulsion was formed where the solid particles from sludge were dispersed evenly. Based on the good matchability of sludge with reservoir, this emulsion may be used as an alternative conformance-control agent. When penetrating into a certain distance, under the influence of dilution and adsorption, the emulsion structure was collapsed, followed by the coalesence of dispersed particles into "clusters" settled downwards in the voids, with the outcome of lower permeability of voids than before and diverting of displacing water. The sweeping volume was increased considerably afterwards. By optimisation, only the high permeability anomalies were plugged, leaving the medium/low permeability area unaffeced.

Compared to other chemical agents for conformance control, this alternative was attractive in such aspects as salt resistant, temperature resistant, shearing resistant and very low contamination with longer action periods.

v)Miscellaneous

Other than what mentione above, there are some other comprehensive utilisation modes, among which are solidification, brick making, fuelization and feedstocks for coking units etc.

In summary, pros and cons of relevant are summarised as follows(Table 2.).

Table 2: Comparison among different treatment modes on oily sludge

\begin{tabular}{|c|c|c|c|}
\hline No. $\begin{array}{c}\text { treatment } \\
\text { process }\end{array}$ & applicability & advantages & disadvantages \\
\hline 1 chemical & $\begin{array}{l}\text { oil content } \\
\text { between } \\
5 \sim 10 \%\end{array}$ & $\begin{array}{l}\text { crude oil } \\
\text { recovered }\end{array}$ & $\begin{array}{l}\text { equipments } \\
\text { and chemical } \\
\text { agents } \\
\text { required; with } \\
\text { the production } \\
\text { and waste } \\
\text { water and } \\
\text { residue }\end{array}$ \\
\hline 2 biological & $\begin{array}{c}\text { all kinds of } \\
\text { sludges }\end{array}$ & $\begin{array}{c}\text { saving energy } \\
\text { and without } \\
\text { chemical } \\
\text { agents }\end{array}$ & $\begin{array}{l}\text { long periods } \\
\text { and oil not } \\
\text { recovered }\end{array}$ \\
\hline 3 burning & $\begin{array}{c}\text { oil content } \\
\text { below } 10 \% \\
\text { and } \\
\text { containing } \\
\text { poisonous } \\
\text { organics }\end{array}$ & $\begin{array}{l}\text { exhausive } \\
\text { remove of } \\
\text { poisons }\end{array}$ & $\begin{array}{c}\text { burning } \\
\text { facilities } \\
\text { required; with } \\
\text { waste gas } \\
\text { giving off; and } \\
\text { oil not } \\
\text { recoverd }\end{array}$ \\
\hline $\begin{array}{c}\text { making } \\
4 \text { fuels and } \\
\text { bricks }\end{array}$ & $\begin{array}{c}\text { all kinds of } \\
\text { sludges }\end{array}$ & $\begin{array}{c}\text { comprehensiv } \\
\text { utilisation }\end{array}$ & $\begin{array}{l}\text { waste gas } \\
\text { giving off and } \\
\text { oil not } \\
\text { recovered }\end{array}$ \\
\hline
\end{tabular}

\section{SELECTION AMONG VARIED PROCEDURES FOR SLUDGE TREATMENT}

In Table 3 the compositional analysis of sludges from united stations of Youfangzhuang and Yunpanshan are presented.

Table 3: Compositional contents of sludges from different blocks

\begin{tabular}{lccc}
\multicolumn{2}{l}{ Sludge source Water(\%)Oil(\%) } & Acid-insoluble residue(\%) & Miscellaneous(\%) \\
\hline Youfangzhuang & 58.10 & 4.00 & 33.20
\end{tabular}

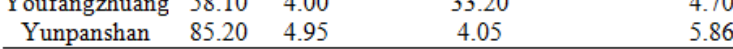

With oil contents below 5.0\%, above sludges are not suitable for treatments chemically; as far as biological ways are concerned, the amount of crude oil loss by bacterials is unneglectable, which is not economical; if burning is resorted to, secondary pollution and waste of oil stand out accompanying the remove of organic poisons; consolidation process, where curing agents sre added in certail ratio to absorb the poisons into lattices, would alleviate the environmental burden of sludges but still not make the most of crude oil. Alternatively, from the points of environments, economy and oil recovery, applying oily sludge as conformance control agents would offer oilfield a scientific and reasonable pathway for comprehensive utilisation. 


\section{APPLICATION PROSPECTS OF SLUDGE AS CONFORMANCE-CONTROL AGENTS IN CHANGQING} OILFIELD

\section{A. Coformance control in Changqing oilfield}

In Changqing oilfield, during the course of development through water flooding, early breakthrough of displacing water is common: For Triassic reservoir with super-low permeability, as a result of prevalent micro-fractures and implemention of hydraulic fracturing, water breakthrough tend to arise on the production wells along the principal stress, while leaving the lateral producers intact; For Jurassic formation, which is rather heterogeneous in character, the channeling of eadge water, bottom water and injection water through highpermeabiblity strands or voids render some wells highly water-cut, other wells bypassed by water. With the lengthening of developmental process, conformance control stick out as a pivotal element for long-term stable yielding in Changqing oilfield.

\section{B. Mechanism on conformance control from sludge}

As for kinds of conforrnan-control agents, the operational mechnisms are distinctly different to each other. The oil and mud from sludge play the key roles for controling efficiency, with the simutaneous Jamin effect generated in formation by emulsion from oil and plugging/settling effects from mud.

\section{Advantages of oily sludge as conformance-control agent}

Compared to other agents, the advantages of oily sludge would be mentioned as follows:

i)Salinity resistance

From the viscosity-salinity relationship curve of common conformance-control agents applied in Changqing oil-production plant \#3(Figure 1), the viscosity discreased abruptly until the salinity reaches about 30000 $\mathrm{mg} / \mathrm{L}$ after which the viscosity tends to be flat, which is detrimental for plugging efficiency resulting from the contraction of polymer coils. While the oily sludge, containing salts within it, was immune to salinity without coil contraction. So, the oily sludge is salinity resistant.

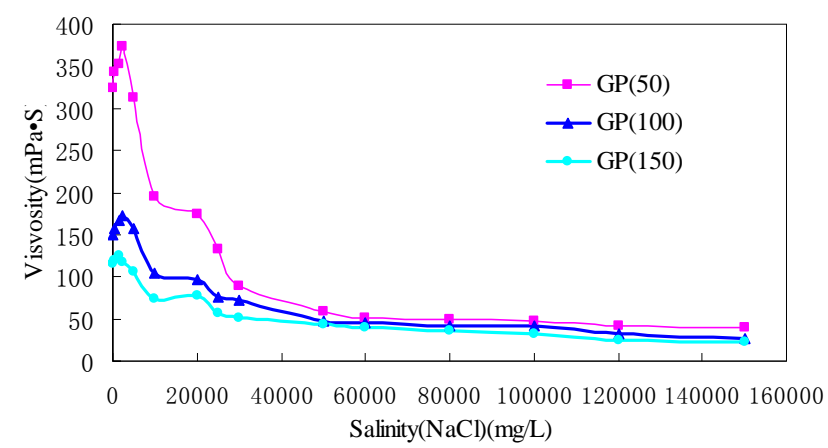

Figure 1: Viscosity-salinity relationship from a conformancecontrol agent

ii)Temperature resistance

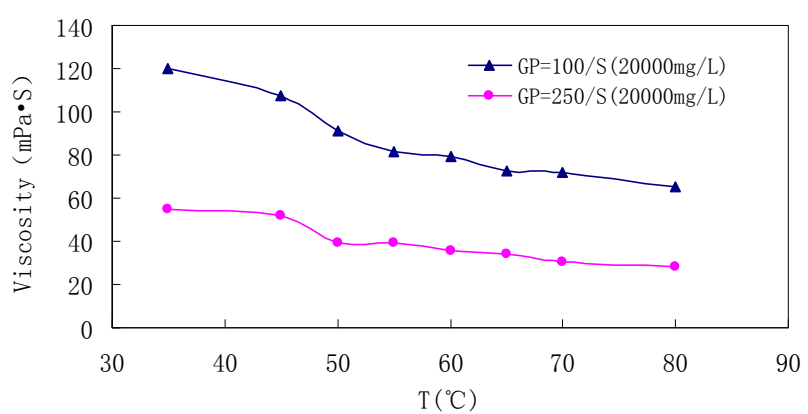

Figure 2: Viscosity-temperature relationship from a conformance-control agent

The viscosity of conventional polymer agents is related to temperature conversely, induced from the contraction of coils likewise, which was indicated in Figure 2. Rather, the oily sludge, originating in the formation with high temperature, is resistant to temperature and a proper candidate for conformance control.

iii)Shearing resistance

Upon injected into formation, especialy with low permeability, the agents are exposed to marked shearing force, which could cause the sanpping off among the polymer chains and weaken the plugging ability. While the viscosity of the oil in sludge wa not affected by shearing; the solid particulates from sludge was unable to be broken likewise. So, shearing condition has not side-effects on the conformance-control performance of oily sludge.

\section{FIELD-TEST CASES}

Field tests applying oily sludge for conformance control in Daqing, Liaohe, Henan ${ }^{[4,5]}$ and Shengli oilfields ${ }^{[6]}$ have achieved satisfied results, from which Zhuangxi area of Shengli oilfield was taken as an example. i) Laboratory experiments

ii)

Table 4 Components from tank-bottom sludge from Zhuanxi united stations

\begin{tabular}{ccccc}
\hline components & $\begin{array}{c}\text { crude } \\
\text { oil }\end{array}$ & water & mud & impurities \\
\hline contents(\%) & 39.62 & 6.97 & 52.31 & 1.10 \\
\hline
\end{tabular}

To disperse the oil-containing sludge into water, surfactants lowering the oil-water interfacial tension was hoped to be added, for the reason of high oil content. Sodium nitrate was choosen as dispersant, with the applied concentration between 0.7 and $1.1 \%$. Consolidation strength of oily sludge, as precipitant of particle type, was not strong, which justified the use of curing agent for better plugging effects. Curing agents of resin type, SD and SG, were indentified, with the applied concentration of $1.4 \%$ and $2.8 \%$, respectively.

ii)Field applications

Conformance control has been executed on 15 wells from this area since september, 1999, with the injection of $1500 \mathrm{~m}^{3}$ of sludge on Zhaung 104-16-19 well group and $1680 \mathrm{~m}^{3}$ of sludge on Zhuang 106-17-16 well group among others. In the conformance control process, the oily sludge was in the concentration of $20 \sim 50 \%$ for favoring injection. After execution, the water-flooding pressure was increased with an average value of over 4 
Mpa. Notably, flooding pressure from Zhuang106-14-19 increased from 7.0 to $12.5 \mathrm{Mpa}$. By testing, the value of pressure index(PI) and full degree(FD) also took the rising tendency, which indicated the high-permeability channels plugged. The injectivity profiles were improved dramatically, with the relative absorption of Layer 22 decreasing from 71.3 to $44.5 \%$ while the relative absorption of Layer 23 increasing from 9.7 to $45.5 \%$.

Untill december, 2011, incremental oil recovery of respective producers, with the proportion of 92\%, from 15 well groups was 12186 tons, in an inpot/output ratio of 1 : 4.1 .

\section{CONCLUSIONS AND SUGGESTIONS}

\section{A. Conclusions}

i)It is not deemed an economical measure using separations, purifications and decompositions for Changqing oilfield oily sludge, characteristic of low oil content(4.0 4.9\%), high water content(58.1 85.2\%) and high mud content(9.9 37.9\%).

ii)It would be a scientific and reliable technology transforming oily sludge into conformance-control agents chemically, having great economic benefits.

iii)A new point was provided on solving pollution of sludge draining, administering the oilfield comprehensively and deducing the production investments.

\section{B. Suggestions}

i)Additional research is required to select proper reservoirs suitble for coformance control by this process.

ii)The chemical formulations of prensent oily sludge agents is required to be improved for best efficiency.

iii)Injection and plugging performance is hoped to be ameliorated by the combination of oily sludge with other conformance-control technologies.

\section{REFERENCES}

[1] Xu R, Wang L, Meng Q. Present Situation and research of treatment of sludge from oil-tanks, Petrochemical Safety Technology, 19(3): 36 39, 2003.

[2] Li F. Effect of the content of chlorine ion on sludge flocculation efficiency, Environmental Production of Oil\&Gas Fields, 3: 40 41, 1999.

[3] Huang X., Chang W. Collecting crude oil from the mud containing oil, Environmental Protection Science, 4(27):7 8, 2001.

[4] Li D., Wang Y., Yu Q., Zhang W. Application and research of profile control of oily sludge, Oil Drilling \& Production Technology, 3(25): 74 76, 2003.

[5] Tang J.,Du X., Hao Z., Zhang H., Zhao Y., Tan H. The research on profile control technology of oil-bearing sludge and its application, Drilling \& Production Technology, 3(27): 86 87, 2004.

[6] Shang Z., Sui Q., Leng Q., Zhang M., Hou L., Zhang L., Chen G. Study and application of oily sludge profile control technique, Journal of Jianghan Petroleum Institute, 3(24): 66 67, 2002. 